\title{
SLUMOSODÁS ÉS VÁROSREHABILITÁCIÓ BUDAPESTEN
}

\author{
(Decline and Renewal - the case of Budapest) \\ TOMAY KYRA
}

Kulcsszavak:

slumosodás városrehabilitáció várospolitika Budapest

A fövâros belsö pesti városrészeinek pusztulása már a rendszerváltást megelözöen is komoly probléma volt, és a nyolcvanas években beindult városrehabilitäciós tervezés ellenére az elmúlt 15 évben is az egyik legjelentösebb várospolitikai kihívás maradt, melyre az egyes kerïletek és maga a föváros is különféle városrehabilitációs stratégiák kidolgozásával válaszolt. Jelen tanulmányban a pusztulás. slumosodás és az egyes rehabilitációs stratégiák, modellek bemutatása, attekintése a cél, elsösorban a kilencvenes évek legjelentösebb rehabilitációs programjának: a középsö-ferencvárosi rehabilitációnak, emellett a belsö-ferencvárosi Ráday utca, illetve a középsö-józsefvárosi Corvin-Szigony projekt bemutatására fókuszálva. Az egyes esetek egy-egy eltérö helyzetre adott várospolitikai válaszokat testesitenek meg, bemutatásukkor erényeik mellett lehetséges veszélyeikre is fel kívánva hivni a figyelmet.

\section{A slum}

A nagyvárosok egyes - különösen az átmeneti övezetben található - városrészeinek leromlása, slumosodása a nemzetközi gyakorlatban régóta ismert jelenség. A slumosodás jelenségével a 20. század elején a Chicagói iskola kutatói foglalkoztak elsőként tudományos megközelítésben.

A természetes övezetek koncepciójában - a Chicagói iskola központi figurája, Robert Ezra Park értelmezése szerint - a slumosodás a központi üzleti negyed expanziójának következtében indult el (Park 1929). A korábbi átmeneti lakóövezetben megjelennek az üzleti funkciók, ezért a várható funkcióváltás miatt a tulajdonosaik nem költenek pénzt házaik felújitására, így a lakóépületek nagy része leromlik. Előbb a tehetősebb rétegek, majd a középosztály tagjai is kiköltöznek a városperemi övezetekbe, helyükre a városi népesség legalacsonyabb státuszú csoportjai, gyakran friss bevándorlók jönnek, akik kedvezötlen anyagi helyzetük miatt itt ragadnak. Helyzetükböl adódóan fizikai környezetüket nem képesek rendben tartani, ami hozzájárul a terület fizikai lepusztulásához, mindennek következtében pedig a közszolgáltatások is elmenekülnek. A slumosodás ekként egy öngerjesztő visszacsatolási folyamat, aminek végeredményeként egy építészetileg, fizikailag erősen leromlott állagú, túlzsúfolt terület jön létre, ahol hátrảnyos helyzetü, „tảrsadalmon kivuuili” csoportok koncentrálódnak. Ennek speciális alesetét képezi az ún. „nagyvárosi gettó”, ahol zömében egy meghatározott, a többségi társadalomtól eltérő szubkultúrával és identitással rendelkező etnikai kisebbség lakik (Wirth 1928). 
A II. világháborút követő nagyléptékü város-átalakításokra reagálva az amerikai Herbert Gans 1959-ben a fentitöl kissé eltéröen értelmezte a slumokat. Öt nem elsősorban kialakulásuk, hanem jövőjük érdekelte, amennyiben elkülönítette a slumot az alacsony bérü övezetektől. Véleménye szerint ez utóbbiakra nagy szükség van egy városban, mivel lehetöséget biztosít a kispénzü és a lakhatási kényelmetlenségeket vállaló egyének, családok számára a központhoz közeli lakhatásra, szemben a slummal, mely ,fizikailag, társadalmilag vagy emocionálisan kárt okoz lakóinak, illetve az egész városnak" (Gans 1973, 419).

\section{A belsö-pesti városrész slumosodása}

Hazánkban és különösen Budapesten nem csak a városi telkek értékváltozásával összefüggő városrész-leromlásról beszélhetünk, hanem a különböző időszakokban lejátszódó pusztulási folyamatok felhalmozódásáról is (Cséfalvay-LichtenbergerPaal 1994).

A föváros belső pesti területein, de különösen a VIII. és IX. kerület külső részein eleve gyenge minőségü lakásállomány épült, melyet kisebb mértékben érintett a főváros 19. század végi, 20. század eleji átépítése. Ezeken a területeken megmaradt az alacsony müszaki színvonalú, döntöen kislakásos bérházszerkezet, ahol már a századforduló óta folyamatosan megtalálhatóak a fỏváros slumterületei (CséfalvayLichtenberger-Paal 1994, 113).

- A II. világháború idején és az ezt követő időszakban jelentős lakosságcsere történt ezen városrészekben (VI.-IX, kerületek), részben a háborús deportálások és kitelepítések, részben a szocializmus idejének lakáspolitikája következtében. Ezáltal a lakások állapotát megőrizni nem képes, abban nem érdekelt társadalmi csoportok költöztek be.

- Az államszocializmus idejének további fontos változása: a lakásállomány államosítása a lakóházak karbantartását, felújítását központi feladattá tette (a HKI, majd az IKV-k kezelésében), ami számos ponton ellehetetlenítette a belsö pesti bérházállomány állagvédelmét, mely tényezőket az alábbiakban részletesen ismertetünk.

Az államszocializmus időszakának felújítási elmaradása, azaz a belső pesti területek nagymértékủ slumosodása speciális jelenség, amennyiben nem a tulajdonosi érdekek, a telekspekuláció, hanem éppen a piaci szemlélet negligálása vezetett az épületállomány rohamos romlásához, nagyobb városrészek slumosodásához.

Ennek része volt a lakásállomány államosítása és az ezzel párhuzamosan mesterségesen alacsonyan tartott lakbére, mely nem fedezte a karbantartás, felújítás költségeit, másrészt a sürgető feladatként jelentkezö ún. „mennyiségi lakáshiány” felszámolás, melyet a „nettó lakásszaporulat” jegyében döntően peremterületi, üres területeken történő nagyszabású lakótelepi újlakás-építéssel igyekeztek enyhíteni. Ugyanakkor a városszéli beépítéseknek más, politikai funkciója is volt, hogy az 1950-ben a fövároshoz csatolt kerületek is „városias” képet kapjanak. A helyzetet tovább rontotta a lokális kötöttségek leszorítására és a központosított, tervutasításos 
rendszerre való átállásra való törekvés, mely sokszor még a Fóvárosi Tanácson is átnyúlva befolyásolta a város szerkezetét. A kerületek azonban szinte egyáltalán nem érvényesíthették érdekeiket. Sok helyen, különösen a VIII. és IX. kerület külső részén, a rekonstrukciós ígéret évtizedekig tartó elhúzódása is rontotta a helyzetet, hiszen az átépítésre kijelölt területen nem lehetett felújítani, csak a minimális életveszély-elhárító beavatkozásokat engedélyezték, mig a környéken megindult építkezések ${ }^{1}$ ezekre a területekre vonzották a keleti országrészből érkező, sokszor alacsony társadalmi helyzetü és roma származású munkavállalókat, tovább erősítve a terület slum-jellegét. Mindennek hatására az 1950-80-as években tovább halmozódott a felújítási hiány. Annak ellenére, hogy az egyes európai nagyvárosokban előforduló, végleg leromlott, homogén slumterületek ma még csak kisebb, néhány száz lakásos zárványokban érzékelhetők Budapesten, a belső-pesti kerületek nagy része elindult a slumosodás útján.

\section{Városrehabilitáció ${ }^{2}$}

A városrészek leromlása, slumosodása - mint azt az amerikai elméletalkotók is felismerték - a város spontán fejlődésének egyik szükségszerü állomása. A slumosodással szorosan összefüggő nagyarányú szub- és dezurbanizációs folyamatok még a leginkább liberális gazdaságú nyugati államokban is rávilágítottak arra, hogy a városok fennmaradását csak ezen spontán slumosodási folyamatba való központi, hatósági beavatkozás állíthatja meg. Ennek a felismerésnek az eredménye, hogy az 1970-es, 1980-as évektől kezdődően számos nyugat-európai, de egyesült államokbeli városban is komoly közpénzeket fordítottak a leromlott városrészek helyreállítására, revitalizációjára. Az egyes országok és városok beavatkozásai azonban a társadalmi felelősségvállalás, illetve a gazdasági liberalizmus adott fokától függően igen változatosak lehetnek. Az egyik szélsőséges válaszlehetőség az, ha a város vezetöi úgy döntenek, „sorsára hagyják” a slumos területet, ez azonban a devianciák, a bünözés, prostitúció, drog elharapózásához vezethet, ami a tágabb városrészre is rányomja bélyegét, míg végül a város egészének jó hírét is leronthatja.

A város döntéshozóinak, cselekvőinek tudatos beavatkozása a városban lezajló negatív folyamatokba, a várospusztulás lassítására, megakadályozására, a társadalmi szint emelésére irányuló intézkedések sorával a tág értelemben vett városrehabilitáció. A városrehabilitációnak különbözö módjai léteznek. Ezek a felújítási formák többnyire nem egy-egy elszigetelt épületre terjednek ki, mindegyiknek az a célja, hogy egy nagyobb városszerkezeti egység egészére hasson a fizikai állapotok megváltoztatásával, és emellett a társadalmi viszonyok ezen keresztül vagy direkt módon zajló átalakításával.

Az elavult tömbök, városrészek megújításának a nemzetkỏzi gyakorlatban tỏbb módszere alakult ki: a teljes vagy részleges bontással járó rekonstrukció vagy más néven „kemény" rehabilitáció, melynek keretében egy városrész, háztömb egészét vagy túlnyomó részét lebontják és új, korszerü épületekkel keltik új életre, illetve az épületek részleges vagy teljes szerkezetének megtartásával járó, ún. „enyhe” rehabilitáció. A megújulásra „megérett” területek megítélésének, kijelölésének fizikai, 
építészeti és társadalmi kritériumai lehetnek. Ezek többnyire nem függetlenek egymástól, ugyanakkor a társadalmi érvek hangoztatása gyakran más - föleg telekspekulációs vagy politikai - érdekek elfedésére szolgál. A városrehabilitáció bevett érvrendszere alapján a slumok kialakulása össztársadalmi szempontból és az adott területen élö csoport szempontjából is káros, ezért az alacsony építészeti érték és az alacsony társadalmi státuszú csoport nem kívánatos koncentrációja miatt többnyire rekonstrukcióval és dzsentrifikációval történő megújítás történik.

Nem feltétlenül kell komoly anyagi ráfordításokkal járó beavatkozást eszközölnie annak a városvezetésnek, aki a negyed státuszromlásának megállítására, megfordítására vállalkozik. Tervezési, szabályozási eszközökkel és kisebb katalizátorbeavatkozásokkal elérheti, hogy a gazdasági befektetök számára valamiért újra vonzóvá váljon a terület (adópolitika, kedvezményes hitelek stb.). Ebben az esetben a legtöbbször a piaci szereplök érdekei mentén radikálisan változik a terület fizikai képe, presztízse és lakossága, de akár funkciója is. A leromlott városrész megújításának „enyhébb”, ugyanakkor jelentös és hosszú távú közösségi, központi forrásokat igénylő formája a szociális városrehabilitáció, amikor a város vagy az állam időnként PPP $^{3}$-rendszerben piaci szereplökkel is társulva - beruház a terület megújításába úgy, hogy annak arculata, lakossága ne változzon drasztikusan. Ennek keretében a házak átépítése és felújitása keveredhet, miközben a lakók egy része helyben maradhat. Nem egyszer munkahelyteremtés és a közszolgáltatások javítása is része a programnak. Természetesen a különféle megújitási stratégiák akár egy városrészen belül is keveredhetnek egymással.

Mivel a város nemcsak müszaki-építészeti-infrastrukturális elemek összessége, hanem társadalmi csoportok szövedéke is, nem megkerülhető kérdés egy-egy beavatkozás társadalmi hatása. A városfelújitás, szanálás mindenképpen jelentős beavatkozás a város társadalmába, az egyes csoportok elhelyezkedésébe, ezért sok vitára ad alapot a hátrányos helyzetü rétegek jelenlegi elhelyezkedését védeni próbáló, a város építészeti értékeit előtérbe helyező, illetve az adott slum feloldását lakosságcserével megoldani kívánó különféle szakértök között. A városi döntéshozók, politikusok mellett a piac önmagában vagy apróbb segítségekkel szintén beavatkozhat, beavatkozik a város társadalmi-építészeti szerkezetébe. Ezen beavatkozások szintén egy-egy terület társadalmi presztízsnövelését célozzák, zömében lakosságcserével megvalósítva azt. Tudatos várostervezési beavatkozások és a piac beavatkozásai egyaránt elvezethetnek az adott területen élö népesség lecserélődéséhez, az alacsonyabb társadalmi státuszú csoportoknak magasabb státuszú csoportokkal való felváltásához, azaz a dzsentrifikációhoz.

A nemzetközi tapasztalatok alapján a hetvenes évekig a túlnyomórészt fizikai rehabilitáció volt jellemző a nyugat-európai nagyvárosokban is, a szociális jellegü „enyhe” rehabilitáció a nyolcvanas évektöl indult el nyugaton. A kilencvenes évektöl azonban újabb váltás figyelhető meg a nemzetközi trendekben: a valóban leromlott, végletesen szegregált területeken a társadalmi struktúra részleges átalakításával, mérsékelt lakosságcserével igyekszenek segíteni. Ebben az esetben azonban hangsúlyozottan nem a piac kiszolgálása a cél (mint a piaci, befektetỏi rehabilitációnál), hanem aktív lakás- 
és rehabilitációs politika révén a terület hosszabb távú stabilitását elősegítő társadalmi heterogenitás megteremtése (Városkutatás Kft. 2004).

\section{A slumosodásra adott válaszok Budapesten az államszocializmus idején}

Budapesten a II. világháborús károk rendbehozatala mellett, valamint azt követően a hatvanas évektől kezdödöen a városrész-leromlásra, avulásra, slumosodásra a rekonstrukció, azaz a szanálás, döntỏen épületek bontása és új beépítés volt a várospolitika válasza. Ezt a stratégiát nem csak az 1950-ben a fövároshoz csatolt külső kerulletek átépítésénél, de az átmeneti övezet, például a VIII, és IX. kerület külső részén is tervezték alkalmazni. A stratégia megvalósulásának eklatáns példáját ma is láthatjuk a józsefvárosi (más néven Szigony utcai) lakótelep formájában.

A Nagykörúton kívül esö, zömmel földszintes vagy egyemeletes, alacsony komfortfokozatú, döntően szoba-konyhás lakások bontásával az 1960-as évektől kezdődően (de az 1980-as évekig elhúzódóan) itt a paneles rekonstrukció eszméje nyert teret. Az első ütemben 1965-re a Tömő utcában épült fel három toronyház, a második ütemben pedig 1975-re közel 2800 lakással megépült az első belvárosi lakótelep, a Szigony utcában. A hetvenes években mind a Körúton belül, mind azon kívül több terület, például a hasonló adottságú Középső-Ferencváros kapcsán felmerült a rekonstrukciós felújitás terve, azonban a legtöbb esetben a magas laksürüség miatt ennek megvalósítása - fơként a lakók ideiglenes vagy állandó elhelyezésének problémái miatt - nem következett be. Ugyanakkor számos területre született ilyen jellegü városrendezési terv, mely a későbbi évtizedek során mintegy felújitási és építési tilalomként funkcionált, nagyban hozzájárulva ezzel ezen területek további fizikai és társadalmi leromlásához.

Az 1970-es évek végétől a fővárosban megindult egy rehabilitációs szemléletü gondolkodás. Részben a mennyiségi lakáshiány csökkenése, részben az igénybe vehető üres területek elapadása, részben a demográfiai szegregáció növekedése ${ }^{4}$ miatt előtérbe keruilt a belső pesti városrészek felújításának, átalakításának kérdése. A nyugati szakirodalomban városrehabilitációként elterjedt értéknövelő felújitásra a hazai szóhasználatban a „tömbrehabilitáció” fogalma vált bevett megnevezéssé, szoros összefüggésben a fövárosban a hetvenes évek végétöl meginduló rehabilitációs tervezési folyamattal, melynek keretében a belső pesti kerületek néhány háztömbjére készültek elöször kísérleti rehabilitációs tervek. Ezek már döntően nem a rekonstrukciós újjáépítést, hanem a meglévő építészeti és társadalmi szerkezet megtartását, a házak, tömbök egészének komplex megújítását és a környezeti helyzet javítását tủzték ki célként. 1980-ra szinte teljesen háttérbe szorultak a belső részek lakóépületeinek lebontását és a teljes újjáépítést hangoztató vélemények, és előtérbe került a lakótömbönként történő „,koncentrált” felújítás terve.

Az 1978-as koncepción alapuló kísérleti VII. kerületi 15-ös tömböt érintö rehabilitáció tapasztalatait is figyelembe véve végül 1986-ban született átfogó fövárosi koncepció a fỏváros belső városrészeinek közel 400 háztömbjére vonatkozóan, amely a fővárosi tanács jóváhagyása után jelentös állami támogatást kapott. 1987töl indult meg a belsö-pesti kerületekben az alapvetöen központi pénzekböl finan- 
szírozott, de kerületi szinten szervezett és kivitelezett „tömbrehabilitációs program". Eszerint a városrehabilitáció a leromlott állapotú városrészek lakóházainak, közösségi intézményeinek, utcahálózatának és városi infrastruktúrájának olyan felújítását jelenti, amely egyfelól törekszik a „városrész jellegzetes szerkezetének, beépítési módjának és az épületállomány értékes részének a megtartására és kiegészítésére”, másfelől „a szociális, városépítészeti, technikai és gazdasági szempontból feltétlenül szuikséges felújításra". A városrehabilitáció szociálpolitikai célja a belső városrészek társadalmi szerkezetének fiatalítása és a „fizikai dolgozók” lakáskörülményeinek javítása volt. Az ,enyhe" rehabilitációt felvállaló 1986-os programról végül nem derült ki, hogy a gyakorlatban hogyan müködhetett volna, mivel részben az anyagi források elapadása, részben a hamarosan bekövetkezett rendszerváltás miatt elakadt.

\section{A városrész-leromlás kihívására adott önkormányzati válaszok a rendszerváltást követöen}

A rendszerváltást követően a döntően közpénzeken alapuló, nem-megtérülő rehabilitáció az állami források elapadása miatt az új gazdasági-társadalmi-igazgatási rendszerben folytathatatlannak tủnt. A finanszírozás mellett a lakásprivatizáció hatására átalakuló tulajdonszerkezet, és az így kialakuló társasházi forma a rehabilitáció szervezését is szinte lehetetlenné tette. A rendszerváltás nyomán az addig le nem zárt felújítási programok céljukat, finanszírozási és kivitelezési módjukat tekintve elavulttá váltak.

A rendszerváltást követő években megtorpant rehabilitációban 1996-97-ben történtek újabb lépések, amikor a föváros jóváhagyta Budapest Városrehabilitációs Programját, és létrehozta a Fövárosi Városrehabilitációs Keretet. A keret pénzügyi alapját kezdetben a bérlakások elidegenítéséból származó kerületi befizetések jelentették. A program részeként a Fővárosi Közgyúlés az egész városban a kerületi önkormányzatok által benyújtott elötanulmányok alapján jelölte ki a rehabilitációs akcióterületeket. Ezek az V.-X. és XIII. kerületben találhatók. Az egyes kerületek rehabilitációs stratégiája eltérö.

Nagyobb, átfogó, rehabilitációra, szerkezetátalakításra alkalmas terület leginkább a VIII. és IX. kerületben maradt önkormányzati kézben, a belső kerületek (V., VI., VII.) esélyét a közpénzböl finanszírozott és közösségi tulajdonú területekre kiterjedő klaszszikus rehabilitációra szinte ellehetetlenítette a nagyarányú bérlakás-privatizáció. Ezért a fóváros belső kerületei ún. akcióterületi rehabilitációs modelleket kerestek.

Az egyik modell az úgynevezett közterületi rehabilitáció. Ebben az akcióban a kerületi önkormányzat - esetleg más közösségi szerepló segítségével - egy teret, utcaszakaszt újít fel, abban a reményben, hogy a közterület felértékelödésével, megújulásával a környezỏ városrész is fejlödésnek indul. Ezek a felújítások ,üzenet" jellegüek a lakosság és a magánbefektetők felé is. A közelmúltban véghezvitt közterủleti rehabilitációk közül a Ráday utca és a Váci utca déli szakaszának felújítása emelkedik ki. Az eleve nagyon jó adottságokkal rendelkező, a város turisztikai 
területei közé tartozó déli Váci utca területén a földszinti üzlethelyiségek gyorsan megújultak, a vendéglátó funkciók a környezö utcákban is sorra megjelentek. A kerületi önkormányzat a saját tulajdonában lévő mủemléképületek teljes felújításával vett részt a folyamatban.

A kerületek által sok helyen elönyben részesített másik módszer a leginkább leromlott, rossz lakás-összetételü - és többnyire önkormányzati tulajdonban lévő ingatlanok bontása és a lakóknak a kerület más részére vagy kerületen kívülre költöztetése. Ezzel a módszerrel az önkormányzatok egyben az adott terület „,szociális” konfliktusait is meg kívánják szüntetni. Általában olyan helyen élnek e lehetőséggel, ahol viszonylag kevés számú ilyen lakóépület ékelődik konszolidáltabb környékbe, illetve, ahol a telek felszabadítása ingatlanpiaci nyereséggel járhat.

A kerületek mindkét stratégia esetén általában a rehabilitált területek ingatlanpiaci felértékelését tartják szem előtt, ehhez egy-egy rehabilitációs gócpontból kiinduló fejlesztéseket támogatnak, remélve, hogy az így elindított projektek a tágabb térségre is hatással lesznek, azt is felértékelik, befektetöket vonzanak oda. Az értékmegörző, felújításos rehabilitáció a befektetői érdekeknek megfelelően kisebb teret kap. A területek felértékelésének az eszköze szinte minden esetben a dzsentrifikációs stratégia, szociális elemek csak annyiban érvényesülnek, hogy a területröl elköltöztetett lakosok magasabb komfortfokozatú, jobb lakásokba kerülnek.

Európa nyugati felén a lakónegyedek fizikai rehabilitációját rendszeresen és tudatosan kombinálják azok szociális és gazdasági megújításával. Az ilyen többcélú megközelítés hiányzik vagy igen kezdetleges stádiumban van Kelet-Európában. „A kelet-európai országokban a várospolitika fö célja - a városmegújítási programok általånos megkésettsége miatt - a fizikai regeneráció, a szociális és gazdasági szempontokat ritkán veszik figyelembe" (Egedy-Kovács-Morrison 2005). A mai budapesti gyakorlatban a piaci alapú, nagymértékü átépítéssel és lakosságcserével járó, dzsentrifikációs városmegújítás az elterjedt. A belsö-pesti kerületekben megindult, döntően piaci alapú átépítések és közterület-felújítások a rehabilitált területekről a szegények elvándorlását és új lakossági csoportok beköltözését eredményezik.

\section{Értékmegőrző rehabilitáció Középső-Ferencvárosban? $?^{5}$}

Az egyetlen sikeresként számon tartott rehabilitáció a IX. kerületben zajlik, azonban mára a terület felértékelödése és a piac fellendülése következtében a nyolcvanas években szociális célokkal megkezdett középső-ferencvárosi városrehabilitációs program is jórészt elvesztette szociális jellegét. Különösen az utóbbi években gyorsult itt fel az ingatlanpiaci (ezért szükségképpen dzsentrifikációs) rehabilitáció. Az akció területe a Ferenc körút - Üllöi út - Haller út - Mester utca által határolt városrész. „Célja a városrész értékmegőrző átalakítása, a lakásállomány struktúrájának javítása és ezen keresztuil a negatív társadalmi folyamatok megállítása, megfordítása" (IX. kerület - Ferencvárosi rehabilitáció 2002).

Ferencvárosban rehabilitációra a megelözỏ vizsgálatok alapján olyan területet jelöltek ki, ahol a város más részeihez viszonyítva a sủrüség - a beépítettség és a lakás- 
sürüség is - alacsony volt, mert ez a terület a 19. és 20. század fordulóján kevéssé épült át a várost sürítő engedékeny szabályozások alapján. Az ipari/kisipari/ intézményi funkciók, a periferiális helyzet és a már akkor is szegény lakosság miatt viszonylag kevés új, emeletes bérkaszárnya keletkezett. Sok helyen tovább éltek a 19. század korábbi évtizedeiböl származó alacsony és lazább beépítésü, sokszor kisléptékü iparral vegyes lakóépületei, amelyeknek bontása ma már a müszaki állapotuk miatt általában indokolt, alacsony értékük és lakásszámuk miatt pedig viszonylag egyszerü. Ezen kívüi jelentös arányban üres telkek is rendelkezésre állnak vagy eredendöen, vagy mert a bennük élö funkció kihalása után a terület alacsony piaci értéke eddig megakadályozta az újbóli hasznosulást.

Középsö-Ferencváros slumosodásában - mint más esetekben is tapasztalható volt, pl. Középsö-Józsefváros, Külső-Terézváros - jelentős tényező volt a rekonstrukciós/rehabilitációs program elhatározása és a megvalósítása között eltelt idő hossza, ez idó alatt gyakorlatilag nem történt felújitás a területen, és ez kedvezőtlenül befolyásolta a területen élők társadalmi összetételét és hangulatukat is. Ennek következtében a terület tartósan leszakadt, és a hátrányos helyzetü rétegek egyik gyüjtöteruiletévé vált. Egyes vélemények szerint a terület „lecsúszása” éppen az 1960-80-as évek közé tehetö.

A IX. kerület felújításának gondolata már 1959-60-ban felmerült, szisztematikus felújítások 1961-62-ben kezdödtek, ezek azonban nem érintették KözépsőFerencvárost, azt „rekonstrukciós területként” tartalékolták, emiatt ezen a területen a felújitás költségeit visszafogták. A rekonstrukciós program a VIII. kerületben kezdödött el, és a ferencvárosi területen is paneles technológiával készülő lakások felépítését határozta meg. A rekonstrukció belső kerületi lakótelepeket kialakító felfogásának kudarcát követően, a nyolcvanas évek elején a Fövárosi Tanács tanulmányterv készítésével bízta meg Locsmándi Gábort, a BME várostervezöjét. A tervek először a paneles építési technológia belső városrészekbe történő beillesztésére vonatkoztak, később azonban a koncepció megváltozott, és a „városi szövet” gazdagítása vált elsödleges szemponttá, széles utcák, fasorok, kis közterek, gyalogos passzázsok és kisebb-nagyobb udvarok kialakításával. A rehabilitációs program azonban financiális okokból csökkentett lakásszámmal és kerületi hatáskörben indult el. Már 1988-ban csökkenni kezdtek a rendelkezésre álló források, $s$ a program végrehajtása rendszerváltás időszakában lelassult. A kerületi önkormányzat 1990-ben alakult meg. Az új képviselötestület tagjai megértették, hogy folytatni kell a rehabilitációt. 1992-ben megalakult az önkormányzati Felújítási iroda, amely 1992-93-ban befejezte az első három lakótömb felújitását. Megváltozott a beépítéssel kapcsolatos koncepció és a felújított lakóingatlanokkal kapcsolatos politika is. A francia mintára alakult SEM IX. Rt. - a vegyes tulajdonú gazdasági társaság (Société d'Économie Mixte- [SEM]) Franciaországban elterjedt formája az ingatlanfejlesztésnek) -, mely 1993 januárjában kezdte meg müködését, a kerületi önkormányzat többségi tulajdonában van, a további 49\%-on az OTP és egy francia beruházási bank (a CDC) osztoztak. Az általuk továbbvitt középső-ferencvárosi rehabilitációs projekt célja az értékmegörző helyreállítás, a lakásállomány struktúrájának javítása, a negatív demográfiai folyamatok megállítása, visszafordítása. 
Mivel a terület városrehabilitációra kijelölt városrész volt, a lakástörvény rendelkezései ellenére sem kellett a lakásokat a bentlakó bérlőknek értékesíteni. A program a fővárosi támogatás hatására 1996-ban kapott ismét lendületet és pénzügyi támogatást a Fövárosi Rehabilitációs Alapból.

A felszabaditott telkeken a befektetők lakó-, kereskedelmi és kulturális létesítményeket építenek. A fejlödés motorja tehát az, hogy az önkormányzati ráfordítások a közvetlen eredményeken túl olyan környezetet teremtenek, amelyben a magántöke számára beláthatóvá és kiszámíthatóvá válik az adott terület fejlödése. A beruházói érdeklődés 4-5 évvel ezelőtt élénkült meg, és azóta tartóssá vált a területen. Az önkormányzati házak felújítása némileg lelassult az elmúlt időszakban. Folynak viszont közterületi felújitási programok, amelyek fokozzák a magántőke beruházásait. A felújítás egyre inkább piacivá válik, ez azonban vélhetően a lakosságcsere fokozódásával is jár. A programot jellemző adatok jól tükrözik annak átalakulását, dzsentrifikációs, rekonstrukciós tendenciáit. 1985 óta az önkormányzat 32 épületet teljesen, 17-et pedig részlegesen felújított, miközben 81 új épület átadására került sor. Ugyanakkor ezen új lakópuületek több mint fele 2000 óta épült, az addigi eredményeket tekintve viszonylag kiegyenlítettnek volt mondható a felújítás és új építés aránya. Az új építésú ingatlanok utóbbi években jellemző magas száma (2001 óta évi 500 lakás feletti átadás) és a felújittásokhoz mért aránya (legalább tízszeres) jól jelzik a rehabilitációs program átalakulását. A legtöbb kritikát ezen a téren kapja az akció, mivel sokak szerint a területen folyó „városrehabilitáció” valójában inkább rekonstrukció, dózerolás, ami eltủnteti a városrész építészeti értékeit és egykori hangulatát.

A középső-ferencvárosi rehabilitációs program az épưletállomány müszaki felújításával és a minőségi lakókörnyezet kialakításával felértékeli az érintett területet. Az önkormányzati épületekben lakó bérlöket nagyobb és magasabb komfortfokozatú lakásokban helyezik el, egyrészt a felújított bérlakásokban, másrészt az önkormányzat által Budapest egész területên vásárolt lakásokban. A felújított, illetve a cserelakások a bérleti szerződés megkötését követöen kedvezményes feltételek mellett megvásárolhatók az önkormányzattól. A program szociálpolitikai célt nem teljesít, a felértékelődés ára (garanciája) a jelentős lakosságcsere. A népességcsere fokozottan érinti az alsó és a legalsó társadalmi csoportokat, illetve a helyi cigány lakosságot.

Várhatóan a jövöben még kevésbé lesznek tarthatók a „klasszikus” rehabilitáció szociális elvei. Az ingatlanállomány piaci felértékelődése már eddig is csak részben tette lehetővé az eredeti lakosság helyben maradását. A piacosodó feltételek nyilvánvalóvá tették, hogy az új építésü lakások nem eladhatók a problémásnak tekintett társadalmi csoportok helyben maradásával, és a rehabilitáció hosszabb távon nem folytatható egy fizetőképesebb lakossági csoport beáramlása nélkül. A dzsentrifikációs folyamat a területen spontán és irányított módon is zajlik. Spontán módon annyiban, hogy a visszaköltöző bérlök egy része késöbb magától elköltözik a területröl anyagi vagy életmódbeli okok miatt, emellett azonban intézményes módon is zajlik a régi lakók ,,szelektálása". A felújított lakásokba visszaköltöző bérlök magasabb lakbért fizetnek, és - a társasházzá alakítást követöen - a (felújított) lakás 
forgalmi értékének 50\%-áért megvásárolhatják bérlakásukat. Ez utóbbi az ingatlanpiaci dzsentrifikációs hatás hordozója.

A területre vissza nem térö lakók elhelyezése a vagyongazdálkodási iroda feladata. A két lehetőség közül - pénzbeli térítés és cserelakás - döntően az utóbbit választják az egykori lakók. A program dzsentrifikációs hatásaira vonatkozó számszerú adat nincs, annyi azonban megállapítható, hogy a rehabilitáció során jelentős lakosságcsere zajlik, melynek oka, hogy a lebontott, illetve a felújítás során összevonásra kerülő lakások bérlöi elköltöznek a rehabilitációs területröl. A területen élők döntő többsége vagy a területen költözik nagyobb és magasabb komfortfokozatú lakásba, vagy a kerület más részein, illetve más kerületekben kap méretében és minöségileg is jobb lakást. A lakásokat a korábban részletezett kedvezmények és feltételek mellett a bérlók megvásárolhatják. A lakástulajdonhoz jutás az érintettek szempontjából döntỏ legitimációs tényezője a programnak.

$\mathrm{Az}$ ún. ,underclass” (szegények, cigányok, a problémás társadalmi csoportok) kiszorítása a területröl ki nem mondott célja/eredménye a programnak. Ezzel képes biztosítani a terület felértékelődését, a magasabb társadalmi státuszú tulajdonosi csoportok beköl tözését. A „kiszorított” családok a kerület, a főváros külső részeinek lakásaiban kerülnek elhelyezésre. Egyes becslések szerint a középső-ferencvárosi rehabilitációs program hatására a területen élő cigány népesség aránya kb. 30\%-ról kb. 5\%-ra csökkenhet. A fejlesztés szereplöi között nincs konszenzus abban, hogy mennyiben szükséges a lakosságcsere a területen. A vélemények a terület teljes „megtisztításától” a lakosság döntö részének megtartásáig terjednek.

\section{Ingatlanpiaci városrehabilitáció Középsö-Józsefvárosban}

A VIII. kerület a leginkább sokszínü kerület a rehabilitációs stratégiákat tekintve. Létezett itt értékmegörző, klasszikus tömbrehabilitáció a belső-józsefvárosi Mikszáth tér környékén, kombinálva a közterületi rehabilitációval, ahol az épületek teljes, majd csak részleges felújitását követöen a lakásokat eladták a bentlakóknak, remélve, hogy a környék ökológiai helyzete elegendö az „önálló lábra álláshoz”, azaz a terület nem fog többé visszasüllyedni, és a karbantartást innentől kezdve a tulajdonosokra, a területen működő intézményekre, vendéglátóhelyekre lehet bízni. Középső-József város északi részén (a Práter utcától északra fekvő területen) komplex, lépésröl lépésre haladó aktív rehabilitáció folyik. A kerületben, a Magdolna-negyedben indul a szociális városrehabilitáció egyik legígéretesebb programja. Az alábbiakban elemzett CorvinSzigony projekt tehát nem a kerület általános stratégiáját tükrözi, pusztán egy az általuk alkalmazott eszközök közül. A Középsö-Ferencvároshoz hasonló helyzetü és adottságú Középső-Józsefváros esetében az ún. „Corvin-Szigony projekt” a leromlott terület gyökeres átalakításán alapuló, a teljes lakosságcserét felvállaló akció. A ferencvárosi modell importálását a közpénzek hiánya akadályozta.

A Középsö-Józsefváros a VIII. kerület központi, legrégebben épült része, melyet csak kismértékben érintett a századfordulón megindult városfejlesztési hullám, ezért a többszintes bérházak a korábbról itt maradt földszintes-egyemeletes házakkal 
felváltva találhatók meg a területen. Az 1960-as évektől kezdve rendszeres bontás folyt itt, először a Szigony utcai lakótelep építése, majd a rehabilitáció előkészítése céljából. Mindennek eredményeként mára a térség fizikailag és társadalmilag is leromlott, foghíjas, heterogén területté vált. A hatvanas évektöl kezdve elmaradt felújitások és a rehabilitáció elhúzódásából fakadó bizonytalanság fokozták a slumosodási folyamatot, ugyanakkor ez a bizonytalanság okozta azt is, hogy a területen viszonylag magas arányban maradtak önkormányzati tulajdonban a lakások, amely megkönnyítheti a tervezett „Corvin-Szigony projekt” elindulását.

A rendszerváltást követően hosszú ideig nem indult el rehabilitáció a VIII. kerületben. 1996-ban az önkormányzat kerületfejlesztési stratégiát készítetett, ekkor döntöttek úgy, hogy a szomszédos IX. kerületben akkor már sikerrel müködő SEM IX. Rt. mintájára 1997-ben Józsefváros is létrehozza saját fejlesztési társaságát RÉV 8 Rt. (Józsefvárosi Rehabilitációs és Városfejlesztési Részvénytársaság) néven. A társaság átmenetet jelent a tulajdonjogok közvetlen önkormányzati gyakorlása és a vállalkozásba adás között. Tulajdonosa a kerület, a főváros és az OTP volt. A társaság feladata a kerületi rehabilitáció tervezése, szervezése, kivitelezése, de emellett ingatlanértékesítéssel is foglalkoznak. A RÉV 8 Rt. 1998-ban készítette el a Józsefvárosi Rehabilitációs Programtervet, melynek legfontosabb fejlesztési elképzelése a belső-józsefvárosi lakóépület-felújitás befejezése, és a középsőjózsefvárosi akcióterület rehabilitációja volt.

Középső-Józsefváros déli részén (Szigony utca - Kisfaludy utca - Üllői út - Práter utca által határolt terület a lakóteleptől befelé) tervezett nagyszabású, jelentős bontással és egy városrész létrehozásával járó, rekonstrukciós ingatlanfejlesztési akció, az ún. Corvin-Szigony projekt nyíltan vállalja fel a lakosságeserét. 2003 öszén négy építöipari társaság ${ }^{6}$ konzorciuma nyert jogot az ország legnagyobb lakóterületi, 20 hektáros vărosrehabilitációs programjának kivitelezésére. A tíz évre tervezett projektben 2500 lakás, üzlethelyiségek és irodák felépítését, parkok kialakítását vállalta fel a megbízást elnyerö cég. A projekt keretében lebontják Budapest egyik legkritikusabb állapotú negyedében a menthetetlen állapotú épületeket, $\mathrm{s}$ helyükre újakat építenek.

Az önkormányzat azzal, hogy egyben értékesítette a területet, a jelenlegi telekárak többszörösét tudta elérni. Az önkormányzat vállailta a terület rendezését, az itt lakó családok elhelyezését, részben a kerület más részén épullö, új önkormányzati bérlakásokban. A területen nagyjából 1100 lakást bontanak, miközben 6-700 önkormányzati bérlakás épưl a kerület különböző pontjain. A sokat támadott projekt kapcsán a kerületi döntéshozók egy része explicit célként, mások csak mellékes következményként értékelik a lakosságcserét, annyi azonban bizonyos, hogy nagyfokú lakosságcsere, dzsentrifikáció fog itt lezajlani az elkövetkező 10 évben.

A kitelepített családok választhatnak a lakás piaci árának megfelelő anyagi megváltás (bérleti jog esetén a piaci érték felével megegyezö összegü), illetve a hasonló értékủ lakás között, a területen maradás alternatívája azonban nem merül fel. A lakókkal való tárgyalások jelenlegi stádiuma alapján a többség az anyagi ellenszolgáltatás mellett dönt. A projektet bonyolító RÉV 8 Rt. véleménye szerint az akció- 
területen jelenleg lakók túlnyomó többsége örül a fejlesztésnek, mivel így viszonylag kedvező feltételekkel szabadulhatnak meg rossz minöségű, kis alapterületü, gyakran komfort nélküli lakásaiktól.

\section{Közterület-rehabilitáció Belsö-Ferencvárosban}

A Ráday utca tekinthető jelenleg a legsikeresebb közterület-rehabilitációnak a fơvárosban. A belső-ferencvárosi Ráday utca fejlesztése a déli Váci utcával ellentétben nem elsősorban turisztikai jellegü. Az utóbbi években az utca fizikai és társadalmi képe is átalakult, a csillapított forgalom, az új díszburkolat és utcabútorok, a megújuló homlokzatok és az egyre-másra nyíló kávézók, sörözök és vendéglök ékes bizonyítékai annak, hogy az utca életében dinamikus változások következtek be az elmúlt néhány évben (Kocsis-Köszeghy-Tomay 2000). Az önkormányzat beruházásai mellett és részben annak hatására a magánfejlesztők, az ingatlantulajdonosok is jelentős fejlesztési és felújítási forrásokat koncentrálnak ide. Ezáltal a Ráday utcában ma már egymás mellett folyik az önkormányzati lakóépületek és intézmények felújítása, társasházi felújítás, szálloda- és irodaépítés, valamint az üzletek, vendéglátóhelyek megújítása, szaporodása.

Belsö-Ferencváros adottságai nagyban különböznek Középsö-Ferencvárosétól, így a rehabilitáció módja is eltérö a két területen. A belső terület a pesti belváros többi részéhez hasonlóan igen sủrủ beépítettségü, magas népsürủségủ. A 19. század második felében és a századfordulón jelentek meg a terület mai képét meghatározó 4-5 emeletes körfolyosós bérházak. Ezen terület felújitása tơbb problémát vet fel, mint Középső-Ferencvárosé. Egyfelől a magasabb lakósürüség miatt jelentősen nagyobb gondot jelentene (mind anyagi, mind pszichés-szociális értelemben) a lakók ideiglenes vagy végleges elköltỏztetése a területről. Másfelől a házak építészeti értéke miatt gyakorlatilag nincs lebontásra érett épület, sỏt nem egy esetben mủemléki felújítást igényelne, melynek megvalósítása drágább, mint a bontás és új épités (erre a foghíjtelkeken van csak mód). Harmadrészt mivel a terület nem volt kijelölve rehabilitációra, a lakások nagy részét privatizálták, így az épületek döntő része vegyes (magán- és önkormányzati) tulajdonú társasházként müködik. A társasházak felújítását nehezíti, hogy akár néhány tulajdonostárs ellenállása (anyagi lehetöségeinek hiánya) is ellehetetlenítheti a felújitást. (A költségeket csökkentheti az önkormányzat pályázati alapon szétosztott támogatása, de önerőre ekkor is szükség van.)

Ezek a körülmények meghatározták az önkormányzat várospolitikai lehetőségeit, ezért az önkormányzat itt más módszerrel próbálta elérni - az eddigi eredmények szerint sikeresen - a terület megújulását. A IX. kerület ezért a területen egy forgalomcsillapított zóna kialakításával egybekötött közterület-rehabilitációs akcióba kezdett, aminek hatására egy sor, mára igen divatossá vált vendéglátóhely települt az utcába. Az utca városközponthoz közeli részén a házak földszintjén, az utcai fronton mármár egymást érik a különféle kereskedelmi és szolgáltatóegységek, többnyire vendéglátóhelyek, pubok, kávézók, sörözők, éttermek. A vendéglátóhelyek elsősorban a viszonylag jó anyagi helyzetú fiatalokat célozzák meg, sokan a közeli egyetemek 
hallgatói közül kerülnek ki. A nyáron utcára néző teraszokat üzemeltető vendéglátóhelyek hamar divatossá váltak.

Az utca vendéglátóipari és kulturális tevékenységet folytató cégei „Ráday Soho” néven egyesületet alapítottak, melynek célja az érdekképviselet, kulturális rendezvények és fesztiválok szervezése, egy jó értelemben vett szórakozó negyed kialakítása. Az egyesuilet biztosítja az etikai minimumot a tagtársak és a vendégek irányában. Az egyesület megállapodást kötött a környékbeli lakókkal a nyitvatartási korlátokról, illetve az utca virágosításával és más kezdeményezésekkel igyekeznek a lakókat „megnyerni”. A kulturális események, fesztiválok között idén immáron ötödik éve vett részt az utca az Ünnepi Könyvhét eseményeiben, filmfesztivált (FilmESfesztivál), kortárs mủvészeti fesztivált (Plain Art), emellett fotókiállítást, jazz-fesztivált, alternatív zenei koncertsorozatot is tartottak.

Ezzel párhuzamosan mind nagyobb lendületet vesz az utcában a társasházfelújitás, bár ez sokszor csak a homlokzat felújitását jelenti. Ma már több a felújított, mint a lerobbant, málló homlokzat az utca belső részén. Ez a két folyamat valószínủleg kölcsönhatásban van, egymás hatását erösítik. Minden valószínüség szerint az utca belső, a városmaghoz közeli részén a jó elhelyezkedés, színvonalas közterület-rehabilitáció és a társasház-felújítások nemcsak az épített környezetet, hanem a társadalomszerkezetet is átalakították. Divatossá vált a város ezen részén lakni, föleg a fiatal értelmiségiek és az új, jól jövedelmező szakmákban dolgozók számára, azaz dzsentrifikációs folyamatok indultak be a területen. Az ingatlanárak, és az ingatlanforgalom is jócskán emelkedett a területen, utalva a felértékelödésre és az intenzív lakosságcserére.

A Ráday utca esete jó példa arra, hogy lehet viszonylag kismértékü közberuházással nagymértékü magánberuházást generálni úgy, hogy az eredmény egy jól használható városi élettér legyen, ugyanakkor kérdés, hogy ez a fejlödés milyen hatással van a közvetlen környezetre. Amennyiben az utca csak ,kirakatként” funkcionál, miközben nem húzza magával Belső-Ferencváros többi részét, sőt egyes vélemények szerint még ront is a környék lakóminőségén például azáltal, hogy a környezö utcák forgalma, az ott parkoló autók száma nő, úgy nem indít be mélyebb városszerkezeti átrendeződést. Kérdés az is, hogy a közösségi szféra képes lesz-e, és mennyiben úgy befolyásolni, keretek között tartani a folyamatokat, hogy az általa képviselendő érdekek és értékek (pl. társadalmi kizárás elvetése, szolidaritás) is érvényesülhessenek.

\section{Szociális városrehabilitáció: a jövő útja?}

A slumosodás megfékezését célzó várospolitikát tekintve az itt bemutatott esetek részben tipikus, részben egyedi esetei a Budapesten folyó rehabilitációs gyakorlatnak. A józsefvárosi és ferencvárosi rehabilitáció a két legnagyobb összefüggő leromlott területtel kapcsolatos stratégiát mutatja be, ennyiben különleges helyzetről van szó, mivel a város más területein nincs hasonló adottságú kiterjedt, de a megújulásra még képes terület. A két nagyobb rehabilitációra megőrzött területen kívül 
a belső pesti bérházas övezetben nincs olyan egybefüggö terület, amit a helyi önkormányzatok „még idöben” kijelöltek volna rehabilitációra, ezáltal mentesülve a bérlöknek történő értékesítés kötelezettségétöl, és megteremtve az egységes, szervezett lebonyolítás feltételeit. A mai helyzetben a vegyes tulajdonú társasházi közösségek rendkívül nehezen szervezhetők össze (a pénzügyi feltételek elöteremtéséröl nem is beszélve), másrészt a városközponthoz közelebb esö, értékesebb területeken a lakósürüség is nagyobb, ami a rehabilitáció egyik fö problémája. Másfelöl az itt elhelyezkedö épületek építészeti értéke is magasabb, ami a rekonstrukció helyett a többnyire költségesebb rehabilitációt teszi szükségessé. A belső-pesti kerületekben ezért gyakoribb a Ráday utcához hasonló közterületi rehabilitáció, illetve kisebb léptékủ, de a fizikai környezet megújítását és a társadalmi szerkezet javítását célul tüző projektek folynak. A belsö-pesti kerületekben szisztematikus megújítás egyelöre nem történt, részben a sürübb beépítés, a privatizált lakások magas aránya és a magasabb, megőrzendö építészeti érték miatt. Ezeken a területeken inkább foghíjbeépítésekkel és kisebb tömbrehabilitációs programokkal találkozhatunk, melyek dzsentrifikációs hatása is nehezebben érhető tetten, bár kétségtelenül létezö. ${ }^{7}$ A szociális rehabilitáció megvalósításának egyik fontos feltétele a rendszeresen befektetett nagyarányú közpénz lenne, ugyanakkor a Fỏvárosi Rehabilitációs Alapba történő befizetéseket több kerület azért tagadja meg, mert az ebböl pályázható támogatások közel felét az utóbbi években a IX. kerület „vitte el”. Föként ezen tényezőknek köszönhetö, hogy a belsö-pesti kerületek nagy része piaci alapú kisebb projekteket indít csak.

Jelenleg tervezés alatt áll egy kísérleti szociális rehabilitációs modell, melynek fö célja a kiválasztott célterületek leromlását okozó folyamatok megállítása és megfordítása, a lakók életminőségének és életesélyeinek javítása. Ennek fő feltétele a célterület szociális stigmatizáltságának csökkentése, ezért amellett, hogy a lakosság nagy részének megtartására törekszik, cél a társadalmi fellazítás, egy mérsékelt lakosságcsere is. A szociális városrehabilitációs terv szerint a beavatkozás a fizikai megújítás mellett a szociálpolitika, lakáspolitika, foglalkoztatás, kisebbségpolitika, közösségfejlesztés komplex eszközrendszerével törekszik az önerőböl megújulni nem képes területek javítására (Városkutatás Kft. 2004). Ilyen területek Budapesten döntỏen a Nagykörúton kívüli átmeneti zónában, a sürü beépítésủ, leromlott lakásállományú városi területeken helyezkednek el. A közeljövöben a Magdolnanegyedben induló szociális városrehabilitációs program vélhetően új irányt fog jelenteni Budapest megújulási stratégiájában, a korábbiaktól komplexitásában, céljaiban is eltérő programok beindulása talán utat mutat a mérsékeltebb lakosságcserével megvalósítható városmegújítás gyakorlatának.

\section{Jegyzetek}

1 A később részletesebben is tárgyalt középsö-józsefvárosi lakótelep-építkezés, mint az egyetlen (félbemaradt) kísérlet a belsỏ városrészek lakóteleppel való rekonstrukciójára.

2 A hazai gyakorlatban a tág értelemben vett városrehabilitáció kifejezést szokták használni minden, a város megújítását célzó beavatkozásra. ugyanakkor az így értelmezett rehabilitáción belül számos 
különbòzó módszer különböztethető meg, melyek egyikét ugyancsak a rehabilitáció kifejezéssel szokás jelölni. Ez a „szüken" értelmezett rehabilitáció a később kifejtésre kerülö „enyhe” rehabilitáció.

${ }^{3}$ Public Private Partnership

${ }^{4}$ Mivel a lakáselosztás a fiatal házasokat preferálta a lakótelepi új lakások kiutalásánál, a régi városrészek lakossága elkezdett rohamosan elöregedni.

${ }^{5}$ A kơzépső-ferencvárosi rehabilitáció múltjâról részletesen ír Locsmándi G. (2005) Városmegújítás a Ferencvárosban - Egedy T. (szerk.) Városrehabilitáció és társadalom. MTA Földrajztudományi Kutatóintézet, Budapest. 201-228. o.

${ }^{6}$ A Középulletépítö Rt., a Hérosz Rt., a Baucont Rt. és a Kipszer Rt.

7 A Belső-Erzsébetváros rehabilitációjáról, dzsentrifikációjáról a folyóirat jelen számának Csanádi Gábor-Csizmady Adrienne-Köszeghy Lea-Tomay Kyra: Belső-erzsébetvárosi rehabilitáció c. cikkében olvashatnak részletesen.

\section{Irodalom}

IX. kerület - Ferencvárosi rehabilitáció. (2002) Budapest.

Cséfalvay Z.-Lichtenberger E.-Paal M. (1994) Várospusztulás és felújitás Budapesten. Magyar Trendkutató Központ, Budapest.

Egedy T.-Kovács Z.-Morrison N. (2005) A városrehabilitációs kezdeményezések nemzetközi tapasztalatai. - Egedy T. (szerk.) Városrehabilitáció és társadalom. Tanulnánykötet. MTA FKI, Budapest. 71-102. o.

Gans, H. (1973) Az avult városrészek lebontásának és az ott élö lakosság átköltöztetésének emberi következményei. - Szelényi I. (szerk.) Városszociológia. KJK, Budapest. 303-324. o.

Kocsis, J.-Kőszeghy, L.-Tomay, K. (2000) Ráday street Budapest. Kézirat.

Locsmándi G. (2005) Városmegújítás a Ferencvárosban - Egedy T. (szerk.) Városrehabilitáció és társadalom. MTA Földrajztudományi Kutató-intézet, Budapest. 201-228. o.

Park, R.E. (1929) The Goald Coast and the Slum. University of Chicago, Chicago.

Văroskutatás Kft. (2004) A szociális városrehabilitáció: koncepció, eszkỏzrendszer és modellkisérletek. Budapest.

Wirth, L. (1928) The Ghetto. University of Chicago, Chicago.

\section{DECLINE AND RENEWAL - THE CASE OF BUDAPEST}

\section{KYRA TOMAY}

The physical and social decline of inner parts of Budapest was already a serious problem in the socialist era before the transition of 1989-90. Although a "soft rehabilitation" method of renewal began in certain areas of the city in the 80 's, most of the concept remained only a plan, due to the transition started in 1989-1990. Urban decline is still one of the main urban policy challenges of Budapest. In this paper my aim is to show how many different renewal policies are exist and followed by the local governments of the different districts, and how these policies effect on the social mix of the areas. The case of Middle-Ferencvaros, InnerFerencváros (Ráday street) and Middle-Józsefváros are examples of different renewal strategies. My aim is to demonstrate both the advantages and disadvantages of the projects. 